\title{
Evolutionary aesthetics as a meeting point of philosophy and biology
}

\author{
Adam Chmielewski* \\ Institute of Philosophy, University of Wrocław, Koszarowa 3/20, 51-149 Wrocław, Poland
}

\section{Abstract}

Metaphysics, or the knowledge of what there is, has been traditionally placed at the pinnacle of philosophical hierarchy. It was followed by theory of knowledge, or epistemology. Practical knowledge of proper modes of conduct, ethics, came third, followed by aesthetics, treated usually in a marginal way as having to do only with the perception of the beautiful. The hierarchy of philosophical disciplines has recently undergone a substantial transformation. As a result, ethics has assumed a central role. The aim of this paper is to suggest that the hierarchy of philosophical disciplines is not yet complete and that one further step needs to be taken. According to the claim advocated here, it is not metaphysics, epistemology or ethics, but aesthetics that is the first and foremost of all philosophical disciplines. This claim is argued for by references to findings of evolutionary aesthetics, especially to Charles Darwin's idea of sexual selection as elaborated in The Descent of Man. I also argue that Darwinian approach to morality is, and should be, derivable from an Darwinian aesthetics which lies at the core of his conception of sexual selection.

Keywords: evolutionary aesthetics, beauty, morality, sexual selection

\section{Transformations of the philosophical hierarchy}

At the beginning of the past century Sigmund Freud has famously remarked that human self-esteem has suffered three great blows. First of them has been dealt by Copernicus who established that earth is not at the centre of the universe, "but only a tiny fragment of a cosmic system of scarcely imaginable vastness"; second one came from Darwin who had invited mankind into the animal kingdom by demonstrating our "ineradicable animal nature"; the third one was a result of the discovery of the Unconscious which brought about the awareness that conscious and rational ego is fact the servant of the unconscious and uncontrollable forces residing in human mind (out of modestly, Freud had ascribed this discovery to Arthur Schopenhauer).

The philosopher of science, Imre Lakatos, introduced a distinction between two kinds of scientific research programmes: progressive and degenerative ones. Despite 150 years since the publication of The Origin of the Species by Means of Natural Selection, or the Preservation of Favoured Races in the Struggle for Life [1], the programme initiated by Charles Darwin shows no signs of degeneration. On the contrary: it continues to inspire such a great host of new theories and ideas that it certainly deserves the name of a progressive one. "Since Darwin's time,

\footnotetext{
*Email: chmielew@uni.wroc.pl

This is an Open Access digital version of the article distributed under the terms of the Creative Commons Attribution 3.0 License (creativecommons.org/licenses/by/3.0/), which permits redistribution, commercial and non-commercial, provided that the article is properly cited.
}

the evidence supporting his theories has become stronger and more comprehensive. The virtually unlimited supply of evolutionary information encoded in the DNA sequence of living organisms allows evolutionists to reconstruct all evolutionary relationships leading to present-day organisms, with as much detail as needed. If you invest the necessary resources (time and laboratory expenses) and you can have the answer to any query, with as much precision as you want. Evolutionists are no longer concerned with obtaining evidence to support the fact of evolution. Rather, evolutionary research nowadays seeks to reconstruct more and more details about evolutionary history and to understand further how the process of evolution occurs" [2].

We may gauge the fertility of the programme by reflecting upon developments in science inspired by his theory, especially in the science of man. It inspired Herbert Spencer in his rather questionable assertions concerning the "natural", and thus desired social order; it has become a background of the evolutionary theories of cognition, language, economics and ethics. There is even an evolutionary theory of the cosmic self-therapy which argues that the damage effected by humans upon the Earth, diagnosed as Disseminated Primatemaia, will generate a healing response, if not a revenge on the perpetrators $[3,4]$.

The transformation mentioned by Freud has left indelible marks on the traditional hierarchy of philosophical disciplines, even if sometimes belatedly. Originally, metaphysics, the knowledge of what there is, has been placed at the pinnacle of the philosophical hierarchy. Aristotle gave it the name of the first philosophy and was followed in this by generations of philosophers for nearly two millennia. Second came the theory of knowledge, or epistemology. Practical knowledge of proper modes of conduct, ethics, came third, followed by aesthetics which has been usually treated in a rather marginal way, as having to do only with the perception of the beautiful. 
This traditional hierarchy has been challenged during Renaissance and Enlightenment periods, especially by Descartes, Hume and Kant. In his Critique of Pure Reason Kant demonstrated that in virtue of the structure of human cognition which he presented, we are not in position to assert for certain the existence of anything in the external world; he compared this discovery to the Copernican revolution. Having deposed ontology from its throne, Kant firmly established priority of the theory of knowledge. He also attached greater importance to both ethics and aesthetics, though they still retained a secondary status vis-a-vis epistemology.

The ancient hierarchy has been revived for a while in a new form by Bertrand Russell who, in The Principles of Mathematics, had attempted to accomplish a deduction of the whole body of knowledge from a parsimonious set of ontological assumptions, influencing in this way a number of thinkers, most notably Ludwig Wittgenstein. A post-modernist rebellion in the 20th century against the traditional philosophical hierarchies, inspired to a significant extent by the work of mature Wittgenstein who repudiated most of his earlier philosophy, has effected a significant reversal. Next steps in this deconstruction deprived the knowing subject itself of its epistemologically privileged, transcendental position. It has been argued that human cognition is affected, both in its content and adequacy, not only by external world, but also by social, political, economic, cultural, and moral factors. This brought an awareness that the knowing subject should be seen as dependent in its cognition upon multifarious influences, and indeed it is constituted by them. As a result, ethics came to be considered the first philosophical discipline [5].

Toward the end of the past century Richard Rorty, incontestably the most popular philosopher of the world of that time, had stressed the importance of Darwin's work to philosophy by saying that it behoves us to "give the self-image Darwin suggested to us a whirl, in the hope of having fewer philosophical problems on our hands" [6]. The aim of this paper is to suggest that evolution of hierarchy of philosophical disciplines is not yet complete, and that one further step needs to be taken. My argument is based on a claim, outlined elsewhere [7], that it is not metaphysics, epistemology or ethics, but aesthetics is the first and foremost of all philosophical disciplines. I shall attempt to demonstrate this claim by helping myself to not so much to Charles Darwin's idea of natural selection, proposed in The Origin of the Species, but rather to his idea of sexual selection, elaborated in The Descent of Man. I shall attempt to show the legitimacy of the Darwinian approach in morals in an indirect way. I shall argue that a Darwinian approach to morality is, and should be, derivable from an Darwin's aesthetics which lies at the core of his conception of sexual selection. In other words, I would like to give a new whirl to the philosophical image of humans, by drawing on some Darwin's ideas.

\section{Duty and the natural selection}

Having finished several chapters of The Descent of Man, Charles Darwin went to Wales for a holiday. He met there a notorious women's rights campaigner, Ms. Frances Power Cobbe. He shared with her a view that men's superiority versus women can be explained by means of the idea of male's struggle for the possession of females; the imperative of possessing females by males endows them with vigour and courage, and even organs, that females lack and are for this reason "underevolved". In her response Ms. Cobbe has lent Darwin a book by Immanuel Kant, apparently in a hope of winning him to the idea of equality of sexes. Even though Darwin remained unconvinced as to the equality of sexes, and expounded a very Victorian view of morality in this regard, Kant's book has inspired him to provide a provisionary answer to the question of the origins of morals [8].

In The Critique of Practical Reason Immanuel Kant expressed his wonder as to the power and the origins of moral duty: "Duty! Thy wondrous thought, that workest neither by fond insinuation, flattery, not by any threat, but merely by holding up thy naked law in the soul, and so exerting for thyself always reverence, if not always obedience; before whom all appetites are dumb, however secretly they rebel; whence thy original?" [Kant (1836; cited in [9])]. This Kantian question has been treated by most philosophers with such a great deal of reverence that few dared to answer it in a way which would depart from Kant. The genius and courage of Charles Darwin lies in the fact that he took up this question, and that had answered it in a revolutionary manner. His answer is formulated in a strictly scientific way, according to the principle of parsimony in scientific explanation, established by Pierre-Simon Laplace. As a well-known anecdote has it, Laplace wrote a five volume book on the solar system, Celestial Mechanics, without mentioning God. When Napoleon asked him: "Monsieur Laplace, they tell me you have written this large book on the system of the universe, and have never even mentioned its Creator", he answered: "I have had no need of that hypothesis".

Even if it has become possible, ever since, to explain the workings of the physical nature without invoking God's name, few ventured to explain human world without reference to religious concepts. This was done by Charles Darwin who in response to Kant's question wrote: "[A]ny animal whatever, endowed with well-marked social instincts, the parental and filial affections being included, would inevitably acquire a moral sense or conscience, as soon as its intellectual powers had become as well, or nearly as well developed, as in man" [9] (almost immediately he relativised this claim by saying that it does not mean that any social animal would acquire exactly the same moral sense as ours, more or less like various animals do have a sense of beauty, though they admire very different objects). In his work he had shown that human morality might be explained without reference to action of non-natural factors or interference of supranatural beings. His explanations had no need for that hypothesis.

\section{Opposition}

From the very beginning Darwin's ideas have been met with hostility from the people of the Church. Among the outspoken opponents of evolution was Samuel Wilberforce, the Bishop of Oxford, who debated Thomas Huxley, "the Darwin's bulldog", challenging him to say whether he claims to have descended from monkey through his father or mother. For this Huxley took a belated revenge when Wilberforce, an excellent horserider, had lost his life after having been shaken off from his ride the very moment he boasted to his companion, Lord Grenville, about his masterly horsemanship, his head hitting a stone. Huxley reportedly commented upon the incident by saying: "For once, reality and his brain came into a contact and the result was fatal" [10]. 
Yet Huxley, an eager disciple of Darwin's, has diverged significantly from his master by arguing that human nature, being a product of the natural world, "red in tooth and claw", is essentially evil. Morality, according to Huxley, is an exclusively human invention aimed to combat and to control selfish and rivalrous tendencies; even if evolutionary processes would not have been possible without them, they have to be tamed in order to make a peaceful and orderly human society possible. " $[\mathrm{T}]$ he practice of that which is ethically best - what we call goodness or virtue - involves a course of conduct which, in all respects, is opposed to that which leads to success in the cosmic struggle for existence. In place of ruthless self-assertion it demands self-restraint; in place of thrusting aside, or treading down, all competitors, it requires that the individual shall not merely respect, but shall help his fellows; its influence is directed, not so much to the survival of the fittest, as to the fitting of as many as possible to survive. It repudiates the gladiatorial theory of existence. It demands that each man who enters into the enjoyment of the advantages of a polity shall be mindful of his debt to those who have laboriously constructed it; and shall take heed that no act of his weakens the fabric in which he has been permitted to live. Laws and moral precepts are directed to the end of curbing the cosmic process and reminding the individual of his duty to the community, to the protection and influence of which he owes, if not existence itself, at least the life of something better than a brutal savage" [11]. He concluded: "Let us understand, once for all, that the ethical progress of society depends, not on imitating the cosmic process, still less in running away from it, but in combating it" [11].

In this way Huxley has separated ethics from evolution, erecting a barrier for the science of biology to have any say about the emergence of human morals. His approach, however, had an important drawback, for within his perspective one would have to abandon the principle of parsimony observed by Darwin in the explanation of human world, by postulating some extra-natural factor responsible for the generation of moral rules.

\section{Morals in nature}

Despite Huxley's claim, a number of studies in sociobiology and evolutionary psychology have successfully attempted to demonstrate that it is possible to explain the emergence and operation of human moral rules, including altruism, sacrifice, justice, love and equality, i.e. the concepts and categories which constitute the essence of human morality, by appealing to principles outlined and suggested by the Darwinian understanding of evolution (e.g. [12-14]). A great number of empirical studies have shown, for example, that Charles Darwin was right in saying that "any animal whatever", having developed social instincts and mental faculties in a sufficient degree, develops also well-defined rules regulating their mutual relations, and that their rules resemble those which are in force among humans. The study of primates have demonstrated that some of them, most notably chimpanzees, orang-utans and capuchins, are displaying altruistic capabilities by sharing food, entering reciprocal exchange transactions, and behavioural expectations. For example, a chimpanzee contender for the alpha position is winning popularity within the group by acquiring and distributing food for his potential allies, to which they normally would not be able to have an access. An undeniable practice of food sharing among primates has been interpreted as a part of the system of mutual obligations, like in the subordinate adult male chimpanzees grooming the dominant alpha male in exchange for the undisturbed mating session or, as among bonobos, an exchange of food is a form of winning sexual favours; or as an act of status enhancement [15].

The primates have also been shown to be capable of conflict resolution and post-conflict reconciliation. "Especially after a serious conflict between two adult males, the two opponents sometimes were brought together by an adult female. The female approached one of the males, kissed or touched him or presented toward him, and then slowly walked toward the other male. If the male followed, he did so very close behind her.... When the female sat down close to the other male, both males would start to groom her and they simply continued when she went off" [15]. They are also capable of showing empathy, sympathy and consolation in distress. De Waal has interpreted these data in the following manner: "Inasmuch as every member benefits from a unified, cooperative group, one expects them to care about the society they live in, and to make an effort to improve and strengthen it. ... Continued infighting, particularly at the top of hierarchy, may damage everyone's interests, hence settlement of conflict is not just a matter of parties involved, it concerns the community as a whole. This is not to say that animals make sacrifices for their community, but rather that each individual has a stake in the quality of the social environment on which its survival depends. In trying to improve his quality for their own purposes, they may help many of their group mates at the same time. A good example is arbitration and mediation in disputes, standard practice in human society - courts of law serve this function - but recognizable in other primates as well" [15].

\section{Sexual selection}

Among things that natural selection, based on the concept of the survival of the fittest, could not explain, is the notorious peacock's tail which certainly does not enhance the survival chances of its owner, but positively reduces them. Yet, despite the tenets of the natural selection, it was there. As Darwin wrote to his friend Asa Grey: "The sight of a feather in a peacock's tail, whenever I gaze at it, makes me sick". Since the complexity of some animal features could not have been explained by means of natural selection alone, Darwin came up with the idea of sexual selection. He elaborated this conception in order to fill a lacuna left by his concentration on the natural selection in his Origins.

A large share of living beings propagate themselves by means of a mechanism known as sex. The biological fact of sex as a means of reproduction, or at least some of its aspects, continue to be mysterious for biologists since sex involves a significant paradox: "benefits of sex are not so obvious as its costs" [16]. There have been many theories attempting to explain why, despite the costs involved in sexual propagation, it had at all evolved. According to the now received view, sexual propagation is a more beneficial mode of reproduction than asexual one because nonsexual organisms are capable of producing only exact copies of themselves. Thus, in case of a change in the environment from hospitable to non-hospitable to the organisms in question, they, together with their offspring, lose a chance to survive and all become extinct. 
In contrast, sexual propagation, even if very costly, enables generation of a more diverse offspring. "If we consider two organisms differing only in that one is sexual and the other not, the sexual does not survive to reproduce any better that the asexual one. In fact, given the costs of finding a mate and otherwise being sexual, a sexual partner may actually be worse off in terms of surviving and reproducing that an asexual one. However, having a diverse group of offspring, a sexual partner may end up with more surviving offspring that an asexual one. If, for example, the habitat becomes colder, only the offspring with heavy furs coats may be able to survive. Even if this type did not exist in the population, two sexual parents may have a chance of producing it through chance recombination of their genes" [16]. Eventually sex, however pleasurable it may happen to be, does not benefit the individuals involved in the sex themselves, but only their offspring, and with them the whole species by increasing a chance of its survival. A modified version of this "variation view of the sex" asserts that sex is really not for parents, offspring, or even for organisms: "The most basic biological consequence of sex is not even reproduction but rather the health and preservation of the genes, or DNA molecules, carried by organisms that practice sex" [16]. The benefit of sex lies in its cleansing and rejuvenating effects of the DNA molecules which are in charge of our biological constitution.

Social animals, primates included, are, as a rule, sexual, which means that they propagate by means of sexual intercourse. As sex is of a paramount importance to the survival of living beings, and since reproductive sex is necessarily a social intercourse, it is of utmost importance for them regulate their sexual traffic. Among reasons for this is the fact that not all effects of sexual intercourses have the rejuvenating and cleansing effect, e.g. the incestual ones. No wonder, then, that sex has always been a subject of elaborate systems of control and regulation. Social animals, in order to survive, have to regulate their social behaviour in this most important aspect of their biological life.

It has been suggested that a rule which may have been crucial in establishing specifically human culture has evolved due to the fact that some primates became capable of regulating their thus far promiscuous sexual behaviour. According to this theory, formulated on a basis of the comparison of humans and chimpanzees, females living in a group have established a rule of their sexual inviolability during the menstruation period, forcing in this way the males to find an another occupation for themselves during that period, for example collecting food to be consumed jointly after the period of untouchability had ended. Furthermore, this practice, apart from being conducive to food procurement and survival, had also the effect that it led males to be more monogamous. In this way they were forced to participate not only in the conception of the offspring, but also in its rearing, which further increased the chances of survival of thus evolved pre-humans. Key role in this has been played by the evolved mechanism of menstrual synchrony among prehuman females which enabled them to form mutual solidarity ties in their relation with males: "females" became "women" when finding themselves in "situation-dependent solidarity... collectively drew on their own biological resources to give their menstrual blood its collectively constructed 'meaning' as a symbol of their inviolability. The consequent rule against rape was the first cultural rule and the foundation on which all other rules were built" [17] (Knight's conception, drawing on Paul Turke's evolutionary theory of sexuality, has been developed in his Blood relations: menstruation and the origins of culture [18]). In other words, thus evolved females made the pre-human societies more egalitarian.

\section{Sex and senses}

According to Aristotle, all humans strive for knowledge which is demonstrated by their love of senses, "especially the sense of sight" [19]. In other words, humans are not only sexual, but also sensual beings. Most of all, however, they are visual beings. Charles Darwin devoted much attention to the role of sensual perception in the regulation of animal sexual behaviour. Having touched upon the topic in The Origin of the Species, he spent much more time investigating this problem in The Descent of Man. Something which fully deserves the name of evolutionary aesthetics plays a fundamental role in his conception of sexual selection.

It is evident that for Darwin sexual selection is an aesthetic selection. "Sexual selection implies that the more attractive individuals are preferred by the opposite sex" [9]. "When we see many males pursuing the same female, we can hardly believe that the pairing is left to chance - that the female exerts no choice, and is not influenced by the gorgeous colours or other ornaments with which the male is decorated" [9]. "When we behold a male bird elaborately displaying his graceful plumes or splendid colour before female ..., it is impossible to doubt that she admires the beauty of her male partner. . . [W]ith great majority of animals, . . . the taste for the beautiful is confined, ... to the attractions of the opposite sex" [9]. In his analyses of behaviour of many species of animals, including humans, Darwin repeatedly remarked upon the fact that differences in their ornamentation and looks are essential for the constitution of their sense of beauty. "If all our women were to become as beautiful as the Venus de Medici, we should for a time be charmed; but we should soon wish for a variety; and as soon we had obtained variety, we should wish to see certain characters a little exaggerated beyond the then existing common standard" [9]. Darwin stresses also the role of olfactory properties and vocal performances in mating of many species, birds, mammals, and humans as well [9].

The visual, or more generally, perceptual display, performed by males for the benefit of females, is nothing but a demonstration of their desire. Male's demonstrated desire works in such a way as to excite a desire in female. From this it follows that crucial role in reproductive success, which is a good strived for by each living being, is played by an ability to make oneself noticed by a possible mate. In this way we may be able to understand that the good of the survival promised by sex, and the beautiful, are intimately intertwined.

The theory of sexual selection and the role played by visuality in sexual species - let us here remark that the meaning of the Latin word species refers to the look, appearance and depiction - enabled him to explain both the promiscuity and lack of discrimination of their partners on the males part, as well as reticence of females and their stronger discrimination in selection of partners for mating. "[M]ales of almost all animals have stronger passions than the females. Hence it is the males that fight together and sedulously display their charms before females; and the victors transmit their superiority to their male offspring" [9]. Males are by nature more promiscuous and less discriminatory, and they will rarely refuse a union with any partner which makes herself available: "the male is generally 
eager to pair with any female" [9]. This is due to the fact that it is in their interest to propagate their genes as widely as possible. Females, in their turn, are both more reticent in their demonstrations of desire and much more choosy, for the burden of rearing the offspring resulting from sex is usually left for themselves only. Yet they are not immune to desire, nor quite helpless; they have a great power of exerting a choice of one, of more, from the suitors: "they can tempt the men whom they prefer, either before or after marriage" [9]. From this we may infer that, at least among humans, very few males will be able to contain themselves when confronted by a skillful demonstration of her desire by a female: few things are more arousing for human males than a demonstration of female's desire. We may also add that few things are more putting off for a human male than female's ridicule of him, or her demonstration of dislike or her feeling of repulsion toward him.

It is worth stressing that, according to Darwin, female's choice is dictated to them by their ability to discriminat the best, i.e. most healthy and promising male from the array of contenders to their sexual favours, the goodness of the partner being assessed by her primarily on the basis of his looks, or his other outward features. In this way, again, we see a close connection between sensuality and sexuality: an ability to perceive is of paramount importance in our orientation in the space of possible sexual relations in the same way as it fundamental to our orientation within the physical space. The intimate relationship between vision and sexuality has been argued for by Sigmund Freud [20]: "A study of dreams, phantasies and myths has taught us that anxiety about one's eyes, the fear of going blind, is often enough a substitute for the dread of being castrated. The self-blinding of the mythical criminal, Oedipus, was simply a mitigated form of the punishment of castration - the only punishment that was adequate for him by the lex talionis".

\section{Evolutionary aesthetics}

It appears, then, that the very concept of beauty that has been ingrained by nature in sexual animals is instrumental in organising and regulating their reproduction and survival, and thus is the most rudimentary form of biophilia. The concept has been formulated by Fromm [21] and subsequently developed by Wilson [22] (see also [23]). Our sexuality made us social beings. Our sensuality played crucial role in regulating both our sexuality and our sociability: it made us moral beings. It should not surprise us, then, that the fundamental connection between the beautiful and the good has been recognised by the Ancient Greeks who used the expression of kalokagathia as the term of moral approval; kalokagathia signified for them what is beautiful and good at the same time. In their deep wisdom the Ancient Greeks had seen the beautiful and the good as originally and inextricably intertwined. The close relationship between the good and the beautiful is still retained in some languages, as it is demonstrated by some usages of the adjective "beautiful" instead of "good" in many languages, Polish among them.

Attempts to recover this original connection between the good and the beautiful within the evolutionary theory, known as bio-aesthetics or evolutionary aesthetics, are relatively recent. According to Wilson, they were pioneered by Gerda Smets in her Aesthetic Judgment and Arousal: An Experimental Contribution to Psycho-Aesthetics [24], but already Thomas
Huxley has written that "Some day, I doubt not, we shall arrive at an understanding of the evolution of the Aesthetic faculty" [11]. An interesting programme of the evolutionary aesthetics has been outlined by Alex Comfort in Darwin and the Naked Lady: Discursive Essays on Biology and Art, where he claims that "there can be a biology of art, as there is a biology of digestion and of motoring". They enabled us better to understand human proclivity to engage into activity known as arts which is as ancient as humans themselves (cf. e.g. [25,26]). Most comprehensive and sophisticated attempt to argue for the validity of Darwin's ideas to the understanding and interpreting human arts has been formulated by Denis Dutton [27].

In this context it has to be remembered, however, that the ability to perceive beauty cannot be confined to the ability of perceiving beautiful objects belonging to the world of arts. Perception of beauty has never been innocent. On the contrary, the rules establishing the ideal of beauty are one of the most repressive means of control in social relations. For beauty has its other, negative counterpart, the ugliness. Albert Camus has defined charm as a quality which procures the answer "yes" before any question has been asked [28]. Conversely, a person devoid of that aesthetic quality will hear most of the time "no" before manages to ask any question. In an analogy to beauty, ugliness never works as a term of aesthetic only, but also of moral disapproval. We may appreciate its power by realising that those who are not aesthetically liked, are branded as ugly, and, as a consequence, are not chosen, and often are actively shunned from, scorned, and rejected. This leads not only to their sexual frustration, but also to their social denigration; reciprocally, it generates in them misogyny or misandry, as the case may be, and often leads, on the part of the rejected, to sexual inwardness, autoeroticism, and sometimes to a revenge - often violent - for having been refused by the opposite sex. Eventually it may also lead to the extinction of the genetic line of those unfortunate who were not fancied by anyone. In this sense the aesthetic ideal of beauty has not only an intrinsic moral, but also a social and political dimension.

One has to stress that, against Darwin's Victorian view of femininity, women have always been conscious of the power invested in them both by their ability to say "no" to men, as well as by the effect that a demonstration of their desire exerts upon them. Rules sanctioning their power over men are known to have been spontaneously established in all cultures. Sarah Blaffer Hrdy convincingly challenged the Darwinian Victorian view of women as by nature passive and monogamous in her The Woman that Never Evolved [29]. This may be explained by reference to the fact that women's desire, in contrast to females of other primates, has become physiologically hidden and has to be actively demonstrated by them to be noticeable, whereas male desire, in men as well as in other primates, is prominent and has to be actively hidden to remain unnoticed.

In the civilised world, the traditionally accepted ways of demonstration of the female desire are now being additionally enhanced and controlled, standardised and diversified, yet most of all ruthlessly exploited by the fashion, cosmetics, popular music and pornographic industries. Moreover, due to the use of the ubiquitous audiovisual media by these industries, demonstrations of female desire - male desire being perceived as too obscene to be publicly depicted - is intensely and extensively employed in the advertising, and is put to work to enhance the aims of a variety of businesses. This adds an important economic dimension to the evolutionary aesthetics. 


\section{Challenges and inspirations}

Charles Darwin's evolutionary theory continues to be challenged as an inadequate explanation of the world of nature and humanity by the advocates of creationism and followers of its more refined version, the so-called intelligent design theory. Archbishop of Vienna, Cardinal Christoph Schönborn has intervened against a view that the Roman Catholic Church has acquiesced in the acceptance of the evolutionary theory or that its perennial teaching became somehow compatible with evolution: "Evolution in the sense of common ancestry might be true, but evolution in the neo-Darwinian sense - an unguided, unplanned process of random variation and natural selection - is not. Any system of thought that denies or seeks to explain away the overwhelming evidence for design in biology is ideology, not science". Quoting the Catechism of the Church, John Paul II, and Benedict XVI, he reminded the faithful that the evolution of living beings, of which science seeks to determine the stages and to discern the mechanism, presents an internal finality which arouses admiration. "To speak of chance for a universe which presents such a complex organization in its elements and such marvelous finality in its life would be equivalent to giving up the search for an explanation of the world as it appears to us. In fact, this would be equivalent to admitting effects without a cause. It would be to abdicate human intelligence, which would thus refuse to think and to seek a solution for its problems" [30].

It has been argued [31] that the creationist beliefs can essentially be reduced to four claims. First claim asserts, rather unsurprisingly, the existence of an omnipotent God. According to the second, even if the explanation of development of life has been elaborated more or less adequately by Darwin, it is God who had directed or otherwise intervened into natural processes through which every living species have come about. Thirdly, creationists and intelligent design advocates agree that human species has certainly been designed and created by God, and that it is an unfounded claim to assert that humans may have evolved from the humanoid ancestors. The above claims are supported by the fourth, most interesting one, according to which some beings, humans especially, are endowed with irreducible complexity which could not have been a work of the purposeless and contingent processes of natural selection of creatures which turn out to be the fittest to survive in a changeable environment.

In an elaborate analysis of the latest attempts to reconcile the scientific, i.e. Darwinian explanations of the natural world, with a variety of religious outlooks, Jerry A. Coyne concluded that "[a]ttempts to reconcile God and evolution keep rolling off the intellectual assembly line ... because the reconciliation never works" [31].

Interestingly, however, the evolutionary theory has been claimed to be inadequate not only by the religiously inspired writers but also by a number of scholars of another persuasion. Most notably Karl Popper, philosopher and methodologist credited with having provided the best available criterion for scientificity, namely the principle of falsifiability, had argued that Darwinism is not falsifiable, and thus unscientific.

According to Popper, Darwinism is a theory which enables us to explain how did it come about that the great variety of forms of life, some of them very complex and refined, have originated from very few of them, possibly even from a single, very primitive organism. Evolutionary theory capable of explaining generation of multitude of forms of life from a very limited number of them (he calls it an evolutionary tree of life) is based, according to him, on four hypotheses. The hypothesis of heredity asserts that offspring of all living creatures resemble "fairly faithfully" their parents. The claim of variation allows for the occurrence of "small" variations in the offspring. The hypothesis of natural selection asserts the existence of a mechanism of control of the offspring by the elimination of the unfit; one of its consequences is that, given the relative stability of the environment, only small variations, caused by small mutations, are allowed to survive, whereas the monstrous mutations turn out, as a rule unfit and thus lethal. The fourth element of Darwinism according to Popper is the claim that variability is being kept with some limit by the natural selection.

Popper went on to say that Darwinism, as it methodologically stands, is not testable because it is unable to predict the outcome of the processes it assumes to be taking place in nature, and for this reason it cannot really explain them. Darwinism is "disappointing" in its predictive and explanatory power for it does not explain in a "scientific way" the concept of adaptation. He says that our usage of the terms "adaptation" and "selection" is that we can say that if a species were not adapted, it would have been eliminated by natural selection. And if a species has been eliminated, it must have been illadapted to the conditions. Adaptation or fitness is defined by modern evolutionists as survival value, and can be measured by actual success in survival, and "there is hardly any possibility of testing a theory as feeble as this" [32].

Despite his own criticisms, Popper awarded Darwinism a status of a metaphysical research programme in Lakatos's sense and claimed that Darwin's theory is invaluable. It has been for him invaluable to the extent that he called his own ideas - in epistemology, methodology, and the philosophy of language the "evolutionary" ones [33]. Following in Darwin's footsteps he claimed, for example, that from amoeba to Einstein is "just one step", the difference being that amoeba, if commits a mistake in its tentative moves within her world, will be eliminated, whereas humans, thanks to their evolved capabilities, will be able to allow their misguided hypotheses to be eliminated in their stead.

We are thus justified to conclude that Popper's methodological misgivings against Darwinian theory have best been answered by Popper himself. We are, too, justified in saying that Charles Darwin's open framework for an explanation of the emergence of humans has provided us with effective tools to explain human reason as a wholly natural phenomenon, and how it may have evolved unaided by anything but natural forces.

Charles Darwin concluded his Origins of the Species on a very aesthetical, but also on a very moral note: “There is grandeur in this view of life, with its several powers, having been originally breathed into a few forms or into one: and that, whilst this planet has gone cycling on according to the fixed law of gravity, from so simple a beginning endless forms most beautiful and most wonderful have been, are being, evolved" [34].

There indeed is an unsurpassed grandeur in this view of humans as beings crafted, in their beauty and morals, by natural forces alone.

\section{References}

1. Darwin C. On the origin of the species by means of natural selection: or, The preservation of favoured races in the struggle for life. London: John Murray; 1859. 
2. Five questions for Francisco Ayala on Charles Darwin and his legacy [Internet]. 2009 [cited 2009 May 11]; Available from: http://www.britannica.com/blogs/20 09/02/ an-interview-with-francisco-ayala-evolutionary-biologistbritannica-contributor-on-charles-darwin-his-legacy

3. Lovelock J. Gaia: the practical science of planetary medicine. Oxford: Oxford University Press; 2000.

4. Lovelock J. The revenge of Gaia Earth's climate in crisis and the fate of humanity. New York: Basic Books; 2006.

5. MacIntyre AC. Dependent rational animals: why human beings need the virtues. Chicago IL: Open Court; 1999.

6. Rorty R. Hilary Putnam and the relativist menace. In: Rorty R, editor. Truth and moral progress: philosophical papers. Cambridge: Cambridge University Press; 1998. p. 48. (vol 3).

7. Chmielewski A. The gaze and touch in the public space. toward the political aesthetics. In: Wrocław Non Stop: Urban Space. Wrocław: Galeria Design; 2008. p. 84-92.

8. More J, Desmond A. Introduction. In: Darwin C, editor. The descent of man, and selection in relation to sex. London: Penguin Books; 2004. p. xlvii-xlviii.

9. Darwin C. The descent of man. London: Penguin Books; 2004.

10. Desmond AJ, Moore JR. Darwin. New York: Warner Books; 1991.

11. Huxley T. Evolution and ethics [Internet]. London: Macmillan; 1894 [cited 2009 May 10]. Available from: http:// manybooks.net/titles/huxleythetext01thx2010.html

12. Ridley M. The origins of virtue. London: Viking; 1996.

13. Ridley M. The red queen: sex and the evolution of human nature. London: Viking; 1993.

14. Baker R. Sperm wars. London: Fourth Estate; 1996.

15. Flack JC, de Waal FBM. "Any animal whatever": Darwinian building blocks of morality in monkeys and apes. In: Katz LD, editor. Evolutionary origins of morality. Imprint Academic; 2000. p. 1-29.

16. Michod RE. Eros and evolution. Reading MA: AddisonWesley; 1995.
17. Knight C. The bloodiest revolution. Tikkun. 1992;7(3):45.

18. Knight C. Blood relations: menstruation and the origins of culture. Yale: Yale University Press; 1991.

19. Aristotle. Metaphysics. p. 980a.

20. Freud S. Writings on art and literature. Stanford CA: Stanford University Press; 1997.

21. Fromm E. The heart of man, its genius for good and evil. New York: Harper \& Row; 1964. (Religious perspectives; vol 12).

22. Wilson EO. Biophilia. Cambridge MA: Harvard University Press; 1984.

23. Kellert SR, Wilson EO, editors. The biophilia hypothesis. Washington: Island Press; 1995.

24. Smets G. Aesthetic judgment and arousal an experimental contribution to psycho-aesthetics. Leuven: University Press; 1973.

25. Wilson EO. Consilience: the unity of knowledge. New York: Knopf; 1998.

26. Voland E, Grammer K, editors. Evolutionary aesthetics. Berlin: Springer; 2003.

27. Dutton D. The art instinct. New York: Bloomsbury Press; 2009.

28. MacIntyre AC. After virtue a study in moral theory. Notre Dame IN: University of Notre Dame Press; 1984.

29. Hrdy S. The woman that never evolved. Cambridge MA: Harvard University Press; 1981.

30. Schönborn C. Finding design in nature. The New York Times. 2005;

31. Coyne JA. Seeing and believing. The never-ending attempt to reconcile science and religion, and why it is doomed to fail. The New Republic. 2009;

32. Popper KR. Unended quest: an intellectual autobiography. London: Routledge; 2002.

33. Popper KR. Objective knowledge: an evolutionary approach. Oxford: Clarendon Press; 1979.

34. Darwin C. The origin of species by means of natural selection: or, The preservation of favored races in the struggle for life. New York: Gramercy Books; 1979. 